\title{
Impacts of alien tree species on the abundance and diversity of terricolous bryophytes
}

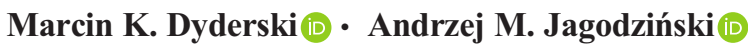

Received: 17 August 2020 /Revised: 21 November 2020 / Accepted: 8 December 2020 / Published online: 10 March 2021

(C) The Author(s) 2021

\begin{abstract}
Bryophytes comprise an important element of temperate forest biodiversity and functioning. Although numerous studies reported impacts of alien tree species on understorey vegetation, few focused on impacts on bryophytes. Here we checked whether three invasive tree species in Europe (Prunus serotina Ehrh., Quercus rubra L. and Robinia pseudoacacia L.) influence terricolous bryophyte communities, alpha and beta diversity, and cover. We used a set of 186 study plots in western Poland with data on the cover of bryophytes species, as well as light availability, soil C:N ratio and $\mathrm{pH}$. We found that light availability was the main driver of bryophyte species richness, cover and composition. Poor Pinus sylvestris L. forests invaded by P. serotina hosted more species and higher species richness than non-invaded $P$. sylvestris forests, while forests invaded by $Q$. rubra and $R$. pseudoacacia hosted fewer species than native forest types. Low differences among forest types studied resulted from small pools of species and the presence of generalist species. Fagus sylvatica L. forest, Q. rubra and R. pseudoacacia forests hosted the smallest number of species, while the most species rich stands were poor $P$. sylvestris forest invaded by
\end{abstract}

M. K. Dyderski $(\bowtie) \cdot$ A. M. Jagodziński

Institute of Dendrology, Polish Academy of Sciences, Parkowa 5, 62-035 Kórnik, Poland

e-mail: mdyderski@man.poznan.pl

A. M. Jagodziński

Faculty of Forestry and Wood Technology, Department of Game Management and Forest Protection, Poznań University of Life

Sciences, Wojska Polskiego 71c, 60-625 Poznań, Poland
P. serotina and non-invaded $P$. sylvestris forests. We concluded that light limitation by invasive species might be more important than dominant tree species identity in limiting terricolous bryophyte species richness and abundance. This requires further studies, accounting for varied abundances of invasive tree species. Therefore, the conservation of sites with high terricolous bryophyte biodiversity needs to be focused on canopy cover.

Keywords community ecology $\cdot$ invasive species impacts $\cdot$ species richness $\cdot$ temperate forest $\cdot$ tree species effect

\section{Introduction}

Alien tree species influence ecosystem functioning by impacts on services and biodiversity (Lövei 1997; Vitousek et al. 1997; Mack et al. 2000). Impacts of alien tree species on ecosystems and human activity vary across species life-history traits and introduction history (Vilà et al. 2011; Potgieter et al. 2017; Castro-Díez et al. 2019). However, some of these impacts reveal consistent patterns, thus, alien species causing similar impacts and driven by similar anthropogenic and biological factors might be assessed jointly, considered as the same invasion syndromes (Novoa et al. 2020). Therefore, assessment of sample species representing a particular invasion syndrome allows inferences about groups of species impacts on biodiversity and ecosystem functioning, as well as to adopt similar management strategies. 
Alien tree species are known for their significant influence on biodiversity and ecosystem functioning because of their high biomass and longevity (Richardson and Rejmánek 2011; Rejmánek and Richardson 2013; Dickie et al. 2014; Castro-Díez et al. 2019). Thanks to species-specific modification of ecosystem properties (Peterken 2001; Mueller et al. 2012; CastroDíez et al. 2019), they may severely influence dependent organisms, e.g. mycorrhizae (Dickie et al. 2017; Rożek et al. 2020), bacteria (Stanek and Stefanowicz 2019), fauna (Karolewski et al. 2020; Mueller et al. 2016) and plants (Taylor et al. 2016; Vítková et al. 2017; Gentili et al. 2019).

One of the taxonomic groups of plants threatened by alien tree species are bryophytes. Due to their dependence on air humidity and affiliation to particular substrata (Fritz et al. 2009; Kriebitzsch et al. 2013; Wierzcholska et al. 2018), bryophytes are sensitive indicators of ecosystem alteration (Vanderpoorten et al. 2004; Rydin 2008; Jagodziński et al. 2018). Moreover, bryophytes comprise a significant proportion of understorey biomass in temperate and boreal coniferous forests (Wirth et al. 1999; Muukkonen et al. 2006; Woziwoda et al. 2014). The low number of specialized species and high species richness has caused most bryological studies to be conducted in wellpreserved ecosystems, especially in old-growth forests (e.g. Snäll et al. 2004; Király and Ódor 2010; Mežaka et al. 2012). Fewer studies have covered managed forests (e.g. Gustafsson and Hallingbäck 1988; Király et al. 2013; Wierzcholska et al. 2018) and post-industrial areas (e.g. Engelmann and Weaks 1985; Jagodziński et al. 2018).

In contrast to numerous studies that assessed impacts of alien tree species on vascular plants, studies focused on bryophytes are scarce and lead to ambiguous conclusions (e.g. Taylor et al. 2016; Sitzia et al. 2018; Slabejová et al. 2019). Moreover, most of them were focused on epiphytes, indicating, for example, high species richness of bryophytes on the bark of Robinia pseudoacacia (Jagodziński et al. 2018; Fudali and Szymanowski 2019) or Q. rubra (Woziwoda et al. 2017). Recent studies revealed decreasing bryophyte species richness and cover in stands of Prunus serotina (Verheyen et al. 2007; Halarewicz and Pruchniewicz 2015; Vegini et al. 2020) or Pinus radiata (Pharo and Lindenmayer 2009). Effects of alien coniferous tree plantations on bryophytes depend on both the life history traits of invasive tree species studied and the properties of the reference ecosystem, and might be both positive and negative (Quine and Humphrey 2010). Therefore, we aimed to compare the impacts of three alien tree species with North American origin (Table 1), which are the most widespread in European woodlands (Wagner et al. 2017) and represent different invasion syndromes (sensu Novoa et al. 2020) due to their functional differences. We hypothesized that invaded forests will impact terricolous bryophyte species composition by decreasing species richness and cover. We also assumed that the relationships will be co-influenced by soil fertility and light availability, due to their importance in earlier studies (Jagodziński et al. 2018).

\section{Material and methods}

\section{Study area}

We established a set of study plots in the Wielkopolski National Park (WNP; W Poland; $52^{\circ} 16^{\prime} \mathrm{N}, 16^{\circ} 48^{\prime} \mathrm{E} ; 7,584 \mathrm{ha}$ ). Due to the presence of numerous alien woody taxa (158 taxa; Purcel 2009), WNP is a good place to study spread and impact of invasive species (Dyderski and Jagodziński 2018, 2019a). The post-glacial landscape, characterized by high geomorphological diversity, determines the occurrence of numerous forest ecosystem types in WNP. The climate in WNP is temperate, with a mean annual temperature of $8.4^{\circ} \mathrm{C}$ and a mean annual precipitation of $521 \mathrm{~mm}$, for the years 1951-2010 (measurements from Poznań meteorological station, ca $15 \mathrm{~km}$ from WNP).

\section{Study design}

In 2014 and 2015 we established a set of 189 systematically arranged study plots, with nine plots in each of 21 blocks (Fig. 1). This system was designed to assess the natural regeneration of the invasive tree species studied (Dyderski and Jagodziński 2018). We selected stands dominated by these invasive species (or in the case of $P$. serotina $-P$. sylvestris dominated stands with understorey dominated by $P$. serotina), based on WNP management plans and field inspection of potential sites. In the center of each block we established one study plot (200 $\mathrm{m}^{2}$ rectangle), in the middle of a 
Table 1 Life-history traits and invasion history of alien tree species studied

\begin{tabular}{|c|c|c|c|}
\hline Species & Prunus serotina Ehrh. & Quercus rubra L. & Robinia pseudoacacia $\mathrm{L}$. \\
\hline $\begin{array}{l}\text { Year of introduction in } \\
\text { Europe as ornamental }\end{array}$ & $\begin{array}{l}1623 \text { or } 1629 \text { (Starfinger et al. } \\
2003 \text { ) }\end{array}$ & before 1637 (Magni Diaz 2004) & 1601 (Cierjacks et al. 2013) \\
\hline Introduction purpose & $\begin{array}{l}\text { ornamental, forest } \\
\text { management, soil } \\
\text { improvement }\end{array}$ & ornamental, forest management & $\begin{array}{l}\text { ornamental, forest } \\
\text { management, soil } \\
\text { improvement, erosion } \\
\text { control, beekeeping, }\end{array}$ \\
\hline Dispersal agents & birds & birds, rodents & wind, water \\
\hline $\begin{array}{l}\text { Dispersal distance in the } \\
\text { introduced range }\end{array}$ & 900 m (Starfinger et al. 2003) & 1,500 m (Riepšas and Straigyté 2008) & $\begin{array}{l}>1,200 \mathrm{~m} \text { (Säumel and } \\
\text { Kowarik 2013) }\end{array}$ \\
\hline $\begin{array}{l}\text { Known impacts on } \\
\text { bryophytes as alien } \\
\text { species }\end{array}$ & $\begin{array}{l}\text { negative (Verheyen et al. 2007; } \\
\text { Halarewicz and } \\
\text { Pruchniewicz 2015; Vegini } \\
\text { et al. 2020) }\end{array}$ & $\begin{array}{l}\text { positive - epiphytes (Jagodziński et al. 2018; } \\
\text { Fudali and Szymanowski 2019) negative - } \\
\text { terricolous (Chmura 2013; Jagodziński et al. } \\
\text { 2018) }\end{array}$ & $\begin{array}{l}\text { positive - epiphytes } \\
\quad \text { (Jagodziński et al. 2018; } \\
\text { Fudali and Szymanowski } \\
\text { 2019) } \\
\text { negative - terricolous } \\
\quad \text { (Jagodziński et al. 2018) }\end{array}$ \\
\hline
\end{tabular}

monoculture of the invasive species. Then, we set up four additional plots, towards the N, S, E and W sides of the central plot, at the boundary of the alien species monoculture and another set of four plots, located 30 $\mathrm{m}$ away from each of the four additional plots. We excluded three study plots which due to systematic design occurred in non-forest ecosystems (thus final $n$ =186).

We assigned each study plot to one of nine categories representing the main types of forest ecosystems in WNP, based on dominant tree species, vegetation and invasion level (Table 2), similarly to Dyderski and Jagodziński (2020). We decided to divide Pinus sylvestris forests into two groups: poor and plantation, according to different management history (Dyderski and Jagodziński 2020). Poor P. sylvestris forests refer to mesic habitats, mostly growing on brunic arenosols, where this species naturally occurs. By contrast, $P$. sylvestris plantation refers to forests occupying more fertile soils, usually cambisols and luvisols, which naturally host Quercus-Acer-Tilia forests. We assigned forests with $P$. serotina individuals with at least 500 ind. $\mathrm{ha}^{-1}>1.3 \mathrm{~m}$ tall as invaded by this species. Forests invaded by $Q$. rubra or R. pseudoacacia were former plantations, and these species comprised $>25 \%$ (mostly $>75 \%$ ) of basal area. The age of dominant tree species within studied forests ranged from 23 to 139 years, and only ten plots had tree stands younger than 60 years old.

\section{Data collection}

Within each study plot we assessed the cover of each bryophyte species using the Braun-Blanquet alphanumeric scale in July of each study year (2015-2018; Electronic supplementary material 1). This produced 742 observations (i.e. four years and 186 plots). We also visually estimated cover of all bryophytes at $5 \%$ intervals. We focused only on terricolous bryophytes, that is, growing on the soil. Taxonomic nomenclature follows Hodgetts et al. (2020). To account for abiotic characteristics we assessed light availability, soil $\mathrm{pH}$ and soil $\mathrm{C}: \mathrm{N}$. We used diffuse non-interceptance (DIFN) - the fraction of open canopy above the understorey - as a proxy of light availability. We measured DIFN in August 2016 using a LAI-2200 plant canopy analyser (Li-Cor Inc., Lincoln, NE, USA) and eight series of ten measurements per study plot. This measurement accounted for minimal light availability during the maximum development of canopy cover. We also collected six soil subsamples, systematically along plot borders, from 0 to $10 \mathrm{~cm}$ depth, and we pooled them into one sample. Then, we measured the $\mathrm{pH}$ of soil solution in distilled water after $24 \mathrm{~h}$ using an electronic $\mathrm{pH}$-meter. Samples were also analysed for total carbon content and total nitrogen content, using the dry combustion method (PN-ISO 10694:2002) and Kjeldahl's method (PN-EN 16169:2012), 
Fig. 1 Schematic arrangement of the study plot blocks ( 21 blocks, each composed of nine plots). Adapted from Dyderski and Jagodziński 2019c

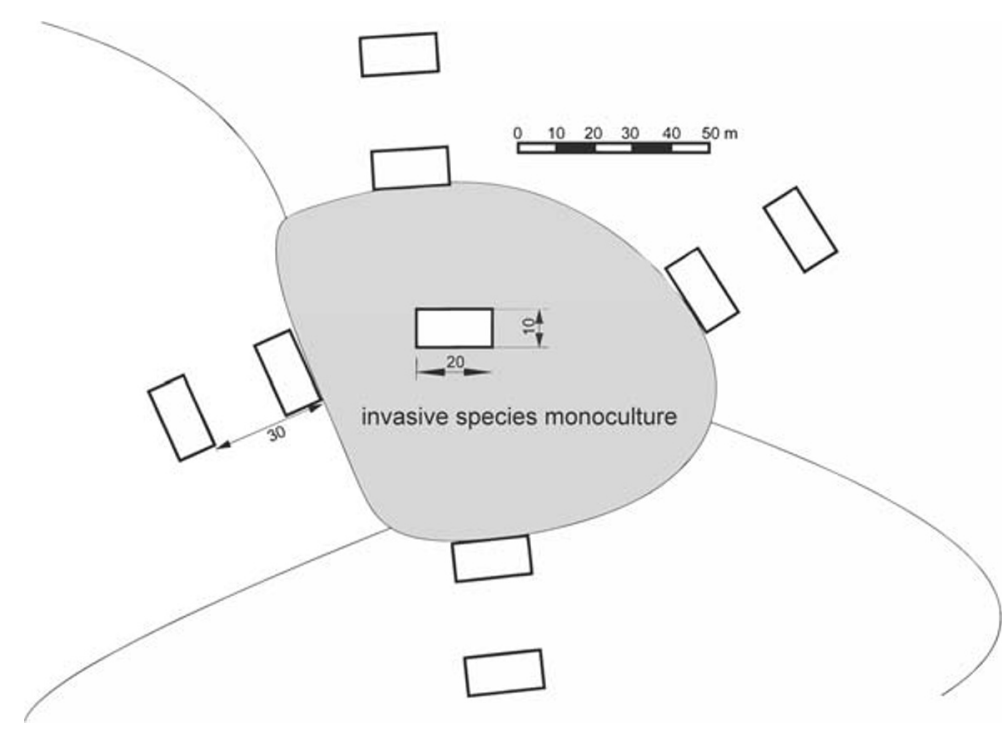

respectively, in an accredited laboratory (Jars Sp. Z o.o, Legionowo, Poland). We used C:N ratio, as a synthetic index of soil fertility.

\section{Data analysis}

We analysed data using R software (v. 3.5.3; R Core Team 2019). Because of the low abundance and species richness, we averaged the cover of each species at the study plot level across all four years of data collection. We used the 'IndVal' method (Cáceres and Legendre 2009), calculated using mean cover data, to check whether a particular species is more frequent in a particular forest type (hereafter 'species pool'), understood as all species occurring in a particular forest type. We used the 'IndVal' method to obtain information about the strength and significance of association (Cáceres and Legendre 2009). We compared bryophyte species composition in each study plot (using square-root transformed data) using non-metric multidimensional scaling (NMDS), based on Bray-Curtis distances. We used the 'vegan' package (Oksanen et al. 2018) to conduct NMDS. Before NMDS we excluded empty observations (i.e. six observations without bryophytes, in NMDS $n=180$ ) To assess the correlation of the main gradients of species composition revealed by NMDS we passively (i.e. without influencing site and species scores) fit soil C:N ratio, soil $\mathrm{pH}, \mathrm{DIFN}$, species richness and cover using the 'vegan::envfit()' function (Oksanen et al. 2018). The goodness of fit was assessed by a permutation test $(n=999)$. We assessed differences in beta diversity among forest types using the vegan::betadisper() function (Oksanen et al. 2018). This analysis checked multivariate dispersion by analysis of mean distance to median of group coordinates in multivariate space. Then, we conducted Tukey's $a$ posteriori tests to assess differences among groups.

We analysed differences in bryophyte cover and species richness using generalized linear mixed-effects models (GLMMs). In models we accounted for random effects describing study design - study plot blocks. To account for plots without bryophytes in GLMMs describing bryophyte species richness and cover, we used zero-inflated models, that is, a compound of the count models and the zero-inflation models. In the count models we assumed Poisson distributions of species richness and beta distribution of bryophyte cover. In the zero-inflation models we assumed binomial distributions. We developed GLMMs using the 'glmmTMB' package (Brooks et al. 2017). In each model we assumed the impact of soil C:N ratio, soil $\mathrm{pH}$ and DIFN, to check the marginal response of forest type accounting for constant levels of other predictors, that is, marginal means, obtained using the 'emmeans' package (Lenth 2019) and marginal responses of continuous variables using the 'ggeffects' package (Lüdecke 2018). We presented models resulting from analysis of variance (ANOVA) type II, based on $\chi^{2}$ tests. We ensured a lack of collinearity among variables by checking variance inflation factors, and we tested zero-inflation and overdispersion using formal tests implemented in the 'DHARMa' package (Hartig 2020). Then, we reduced 


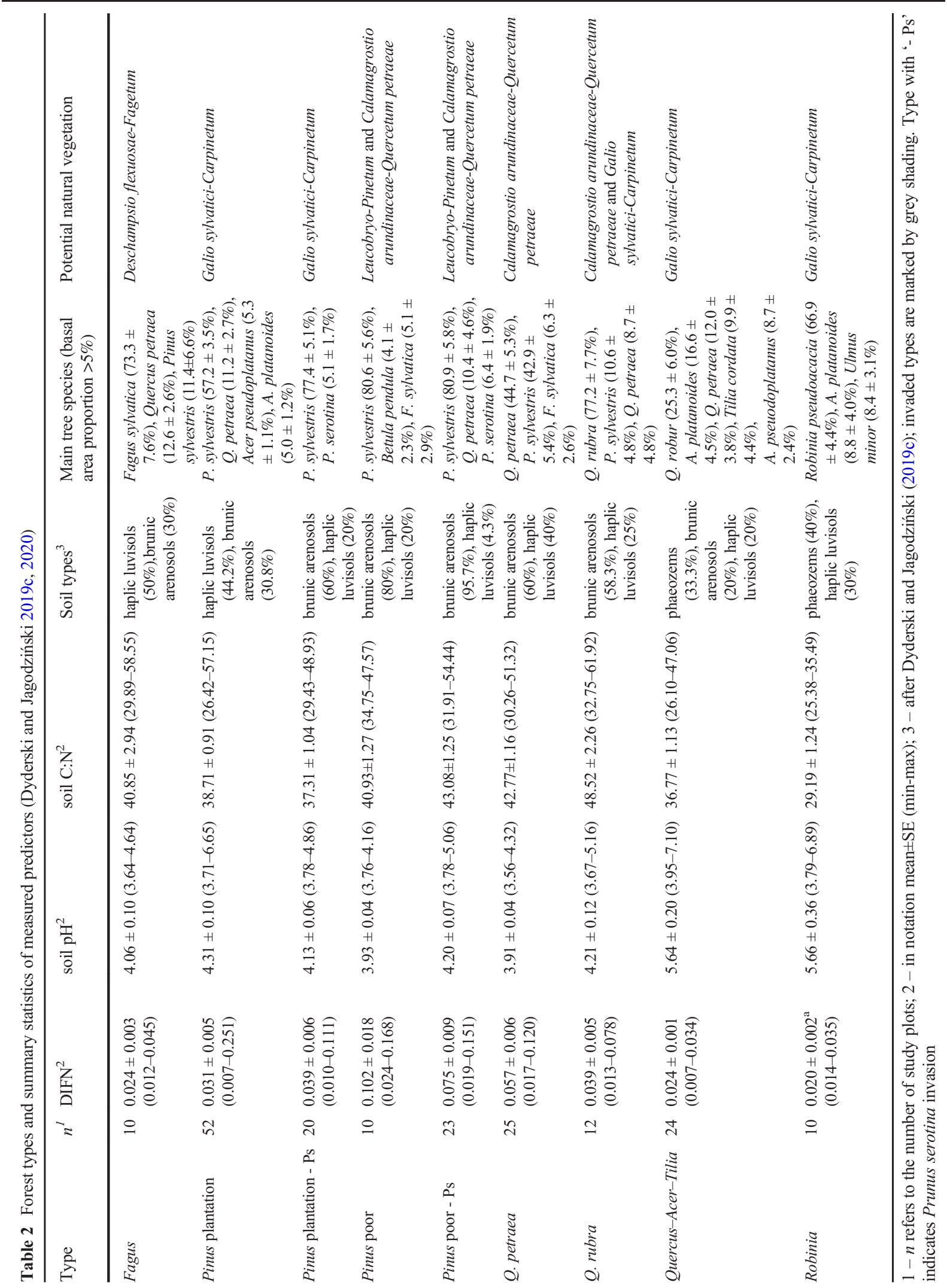


variables in each model to decrease the Akaike information criterion, corrected for a small sample size $(\mathrm{AICc})$.

\section{Results}

During our study we found 25 bryophyte species in 180 of 186 study plots (Table 3). Among them, the most frequent were Brachythecium salebrosum (occurring in 93.5\% of the plots), Hypnum cupressiforme (54.3\%), Pohlia nutans (54.3\%), Aulacomnium androgynum (40.3\%), Dicranella heteromala (39.8\%) and Atrichum undulatum (39.2\%). Analysis of species frequency and association to particular forest type revealed that noninvaded $P$. sylvestris plantations differed from all other $P$. sylvestris forest types by lower frequency and abundance of Pleurozium schreberi, Pseudoscleropodium purum, Dicranum scoparium and D. polysetum (Table 3). Non-invaded poor $P$. sylvestris forests were characterized by the exclusive occurrence of Brachythecium albicans. Quercus-Acer-Tilia forests differed from other forest types by the presence of indicative Fissidens taxifolia. Non-invaded $P$. sylvestris plantations and $P$. serotina invaded poor $P$. sylvestris forests hosted the highest number of species, while Fagus and Robinia hosted the lowest number of species (Table 3). We found that invaded forests usually hosted fewer bryophytes than non-invaded: only in the case of poor P. sylvestris forests did the invaded forest type host a higher number of species than noninvaded (Table 3).

Bryophyte communities in study plots ordered along NMDS1 axis (Fig. 2) from forest types with low soil C:N ratio and light availability (Quercus-Acer-Tilia, Robinia, Fagus, Q. rubra and Q. petraea) to high ( $P$. sylvestris forests, with the exception of noninvaded plantations). However, within these two groups forest types overlapped. NMDS1 gradient was correlated with bryophyte cover, DIFN, and soil C:N ratio. The cluster of $P$. sylvestris forests (both invaded and noninvaded) was affiliated with Pseudosleropodium purum, Hylocomium splendens, Dicranum scoparium, D. polysetum, and Pleurozium schreberi. Invaded and non-invaded plots overlapped in NMDS space. Analysis of beta diversity revealed that forest types differed in mean distance from the median (d.f. $=8, F=3.9315, P=$ 0.0002 ), with the highest within-group dissimilarity in
F. sylvatica forests and the lowest in Q. rubra forests (Fig. 3).

Bryophyte cover depended on forest type and light availability (Fig. 4, Table 4). We found the highest cover in poor $P$. sylvestris forests, both uninvaded $(18.5 \pm 4.2 \%)$ and invaded $(12.6 \pm 2.5 \%)$ while the lowest - in Q. petraea, Fagus, and Q. rubra forests $(4.0 \pm 1.1 \%, 3.9 \pm 1.4 \%$ and $3.3 \pm 1.0 \%$, respectively $)$. Bryophyte cover also increased with increasing DIFN (Fig. 5). Bryophyte species richness depended on forest type, soil $\mathrm{pH}$, soil $\mathrm{C}: \mathrm{N}$ ratio and light availability (Fig. 4 and 5, Table 4). We found the highest bryophyte species richness per plot in poor and plantation $P$. sylvestris forests, both invaded by $P$. serotina $(7.3 \pm 0.7$ and 6.1 \pm 0.6 , respectively), while the lowest species richness occurred in F. sylvatica forest $(2.9 \pm 0.6)$. Bryophyte species richness increased with increasing DIFN and decreased with increasing soil $\mathrm{pH}$ and soil $\mathrm{C}: \mathrm{N}$ ratio (Fig. 5). However, the effect of DIFN was the highest, while the effect of soil $\mathrm{C}: \mathrm{N}$ ratio was the lowest.

\section{Discussion}

Impact of Prunus serotina on terricolous bryophytes

We found different impacts of $P$. serotina invasion on bryophyte response: invaded poor $P$. sylvestris forests had higher terricolous bryophyte species richness per plot, but lover cover, than non-invaded, while invaded $P$. sylvestris plantations had both higher species richness and cover than non-invaded. This might be connected with different levels of available resources in both types of $P$. sylvestris forests, making $P$. sylvestris plantations more susceptible to colonization by both alien and native species (Zerbe and Wirth 2006; Jagodziński et al. 2015). As our model accounted for light availability, our results contradicted previous studies indicating the negative effects of $P$. serotina on bryophyte species richness (Verheyen et al. 2007; Halarewicz and Pruchniewicz 2015; Vegini et al. 2020). This might be connected with the high capacity of $P$. serotina for light interception (Urban et al. 2009; Jagodziński et al. 2019), resulting in different biomass allocation patterns by developing a large canopy, relative to its biomass (Dyderski and Jagodziński 2019a).

In $P$. sylvestris plantations invaded by $P$. serotina we found more bryophytes typical of acidophilous coniferous forests than in non-invaded, for example 


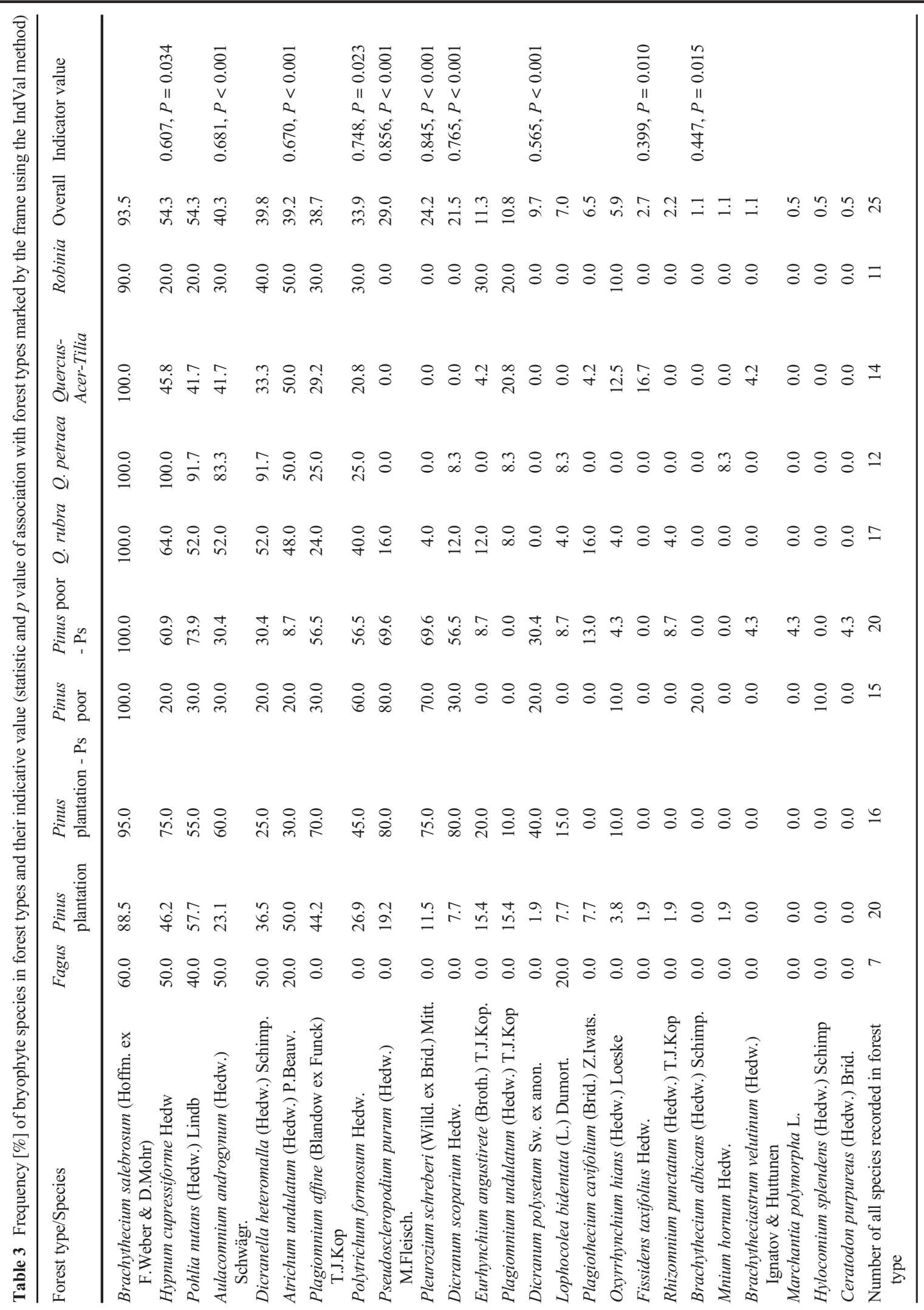


Fig. 2 Result of non-metric multidimensional scaling (NMDS; stress $=0.1924)$, points represent site scores for each study plot. Ellipses delimit 95\% the confidence area for each forest type. Italicized labels represent species scores and are abbreviations of species names (e.g. Mniuhorn = Mnium hornum). Bold names and arrows represent passively fitted environmental variables: soil $\mathrm{pH}$ $\left(\mathrm{pH}, R^{2}=0.139\right)$, soil $\mathrm{C}: \mathrm{N}$ ratio (C:N, $\left.R^{2}=0.120\right)$, light availability (DIFN, $R^{2}=0.361$ ), terricolous bryophyte species richness (rich, $R^{2}=0.496$ ) and total cover of bryophytes (cov, $R^{2}=0.644$ )

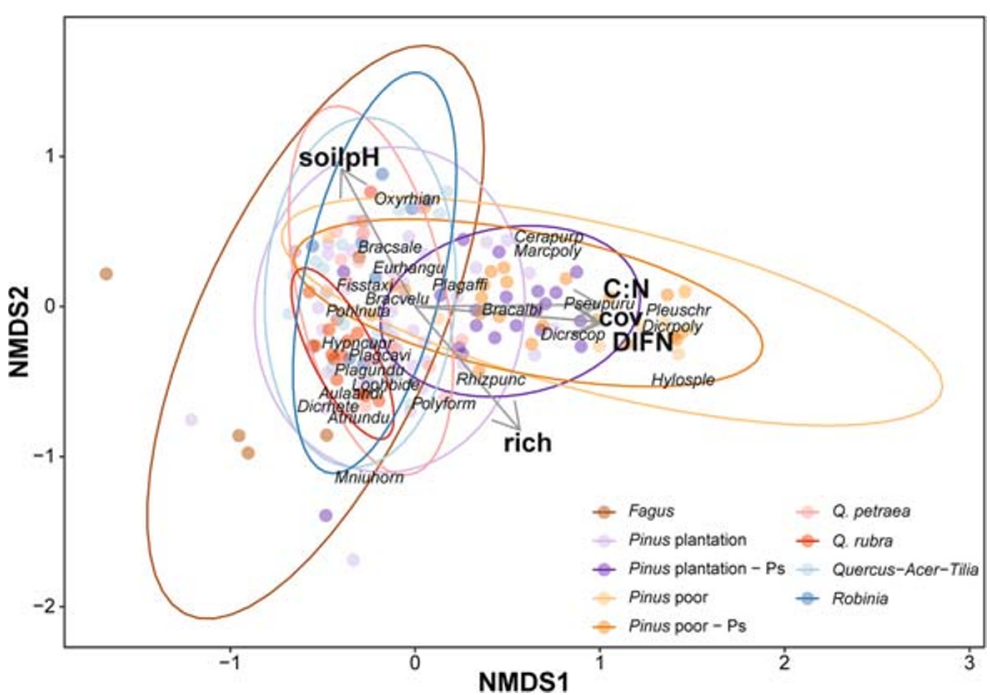

Pseudoscleropodium purum, Pleurozium schreberi or Dicranum scoparium. However, at larger scales these species are generally frequent in all $P$. sylvestris-dominated forests. This might be connected with limiting the

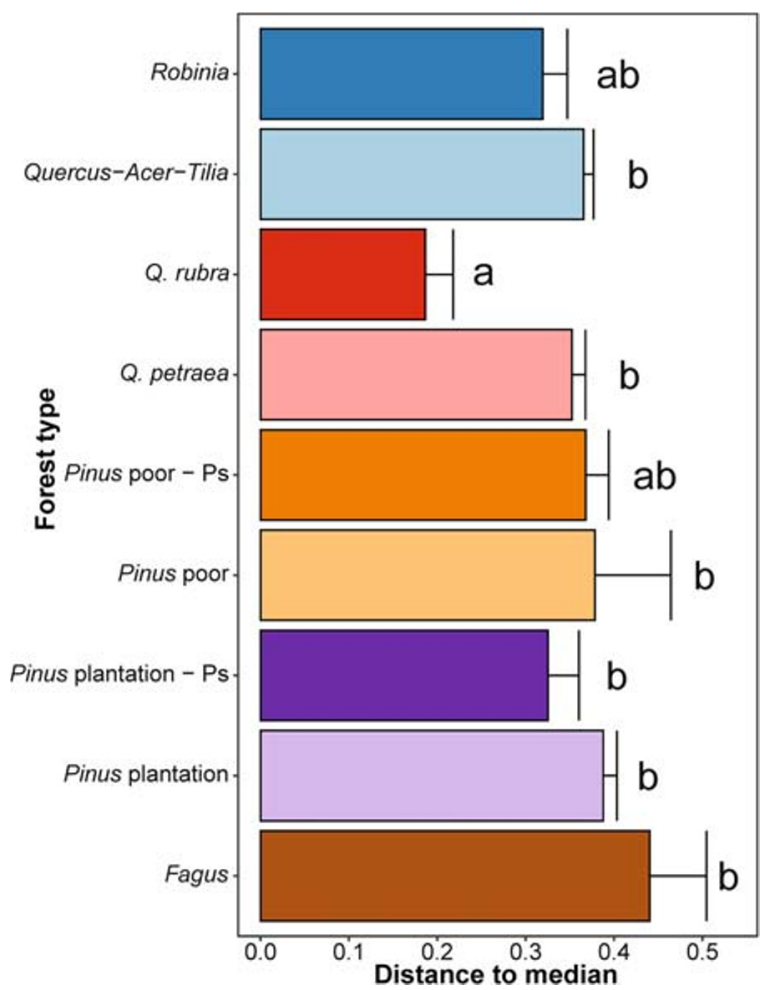

Fig. 3 Mean $(+S E)$ distance from group median in multivariate space, indicating multivariate homogeneity of group dispersions for the forest types studied. Same letters denote groups which did not differ at the confidence level $\alpha=0.05$ after multiple hypotheses adjustment, according to Tukey's a posteriori test growth of graminoids and forest-edge forbs by $P$. serotina, which usually colonize $P$. sylvestris plantations (Zerbe and Wirth 2006). In poor P. sylvestris forests addition of $P$. serotina might create microsites suitable for colonization by the generalist Hypnum cupressiforme. However, lack of difference in soil C:N ratio between invaded and non-invaded poor $P$. sylvestris forests does not support this suggestion. Different patterns of $P$. serotina impacts on bryophytes in P. sylvestris plantations and poor forests are an example of the context-dependence of biological invasion (González-Moreno et al. 2014; Dyderski and Jagodziński 2019b; Sapsford et al. 2020). Here, a mismatch between habitat fertility and forest species composition changed the impact of an invasive tree species on bryophytes.

Impact of Quercus rubra on terricolous bryophytes

We found that Q. rubra forests had smaller terricolous bryophyte species pools than all other forest types except F. sylvatica and R. pseudoacacia forests. In our study $Q$. rubra forests hosted a lower proportion of bryophytes than in post-industrial forests, where Q. rubra forests had 38 of 82 species recorded as terricolous (Jagodziński et al. 2018). Similarly, in two types of Q. rubra forests Woziwoda et al. (2017) found 38 species of terricolous bryophytes. Despite the lowest mean bryophyte cover, $Q$. rubra forests hosted a relatively constant set of bryophyte species. This was mainly driven by four species: Brachythecium salebrosum, Hypnum cupressiforme, Dicranella heteromala and 
Fig. 4 Marginal mean $(+S E)$ bryophyte species richness per plot and cover for forest types studied. Same letters denote groups that did not differ at the confidence level $\alpha=0.05$ after multiple hypotheses adjustment, according to Tukey's a posteriori test; for model details see Table 4

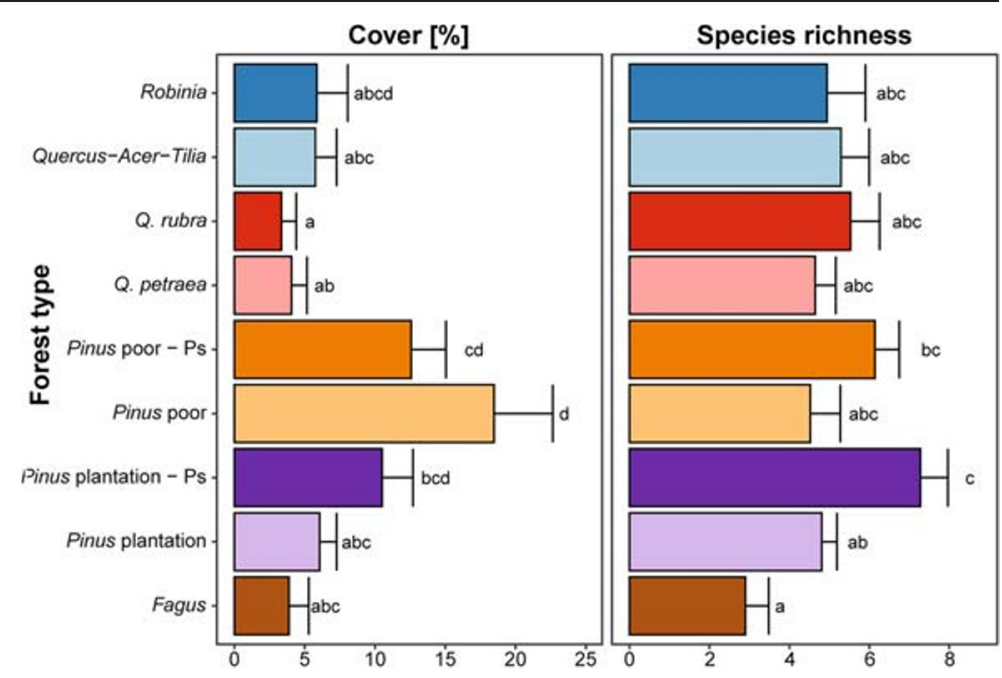

Aulacomnium androgynum - two generalists and two specialists occurring mainly near the root collar. The three latter species revealed fidelity to $Q$. rubra forests, and also occurred with higher frequency in $F$. sylvatica and $Q$. petraea forests, which are similar to Q. rubra in terms of soil fertility and community structure (Chmura 2013; Major et al. 2013; Dyderski et al. 2020). This group of relatively constant species drove high species richness, and resulted in low beta diversity, expressed by mean distance to the median (Fig. 3) of terricolous bryophyte assemblages in $Q$. rubra forests. Therefore, high species richness of epiphytic bryophytes on Q. rubra (Woziwoda et al. 2017; Jagodziński et al. 2018; Fudali and Szymanowski 2019) may affect the terricolous pool by expansion from root collars onto the soil. This speculation needs further experimental confirmation.

Impact of Robinia pseudoacacia on terricolous bryophytes

We found that only $F$. sylvatica forests had smaller species pools of terricolous bryophytes than $R$. pseudoacacia forests, as well as low species richness and cover. As $R$. pseudoacacia forests occupy fertile soils, where natural forests host low diversity of terricolous bryophytes, there are almost no data about $R$. pseudoacacia impacts. Relatively high (within a studied dataset) species richness per plot is also connected with the presence of generalists - Brachythecium salebrosum and Atrichum undulatum, as well as with generally high soil fertility. This resulted in the lowest beta-diversity (Fig. 3) among forest types studied and low distinctiveness. The level of species richness and cover in $R$. pseudoacacia forests was similar to Quercus-Acer-Tilia, which might be a reference forest type in terms of soil fertility. However, due to the high number of generalist bryophyte species, their composition in R. pseudoacacia forests is closer to P. sylvestris plantations. This indicates that $R$. pseudoacacia contributes to the biotic homogenization of terricolous bryophytes assemblages.

Impact of study design and methodology

Both models of species richness and cover revealed the high importance of both light availability and forest types. Therefore, marginal responses revealed in our study were adjusted to standard light availability (Fig. 4). In this way, we separated species-specific effects from light availability effects, which are important drivers of bryophyte occurrence (Rydin 2008). Therefore, accounting for differences in bryophyte cover and biodiversity needs to refer to light availability, as the factor determining both species occurrence and abundance. Light availability is strongly modified by dominant tree species (Peterken 2001; Niinemets 2010; Dyderski and Jagodziński 2019a). Therefore, light limitation seems to be the main mechanism of invasive tree species impacts on bryophyte communities. Another factor affecting study design is the choice of the reference ecosystem. Our study accounted for multiple 
Table 4 GLMM models of species richness and cover

\begin{tabular}{|c|c|c|c|c|}
\hline \multirow[t]{5}{*}{ Bryophyte cover } & Variable & $x^{2}$ & D.f. & $\operatorname{Pr}\left(>\chi^{2}\right)$ \\
\hline & DIFN & 104.8 & 1 & $<0.0001$ \\
\hline & forest type & 42.2 & 8 & $<0.0001$ \\
\hline & $\mathrm{AICc}$ & $\mathrm{AICc}_{0}$ & block $S D$ - conditional & block $S D$ - zero-inflation \\
\hline & -525.1 & -396.5 & 0.495 & 0.782 \\
\hline \multirow[t]{7}{*}{ Bryophyte species richness } & Variable & $x^{2}$ & D.f. & $\operatorname{Pr}\left(>\chi^{2}\right)$ \\
\hline & soil $\mathrm{pH}$ & 8.8 & 1 & 0.0030 \\
\hline & soil $\mathrm{C}: \mathrm{N}$ & 0.6 & 1 & 0.4426 \\
\hline & DIFN & 7.6 & 1 & 0.0058 \\
\hline & forest type & 28.7 & 8 & 0.0004 \\
\hline & $\mathrm{AICc}$ & $\mathrm{AICc}_{0}$ & block $S D$ - conditional & block $S D$ - zero-inflation \\
\hline & 911.6 & 934.9 & 0.115 & $<0.0001$ \\
\hline
\end{tabular}

$\mathrm{AICc}-$ Akaike information criterion, corrected for small sample size, $\mathrm{AICc}_{0}-\mathrm{AICc}$ of the null model (intercept-only), DIFN - diffusive non-interceptance (light availability proxy), $\chi^{2}$ - test statistic; random effects $S D$ are standard deviations of block random effects in models, accounting for spatial samples dependence - conditional is $S D$ from the conditional part of the models (estimation of value) and zeroinflation - from the zero-inflation part of the models (estimation of non-zero value probability)

native forests, which might be replaced by invasive species. This expands our inference regarding predicted impacts of invasive species on bryophytes to multiple types of native ecosystems. However, the application of a 'treatment-control-removal' approach would have benefits in understanding invasion legacies (Barney et al. 2015), which are important in bryophyte responses to habitat transformation (Pharo and Lindenmayer 2009).
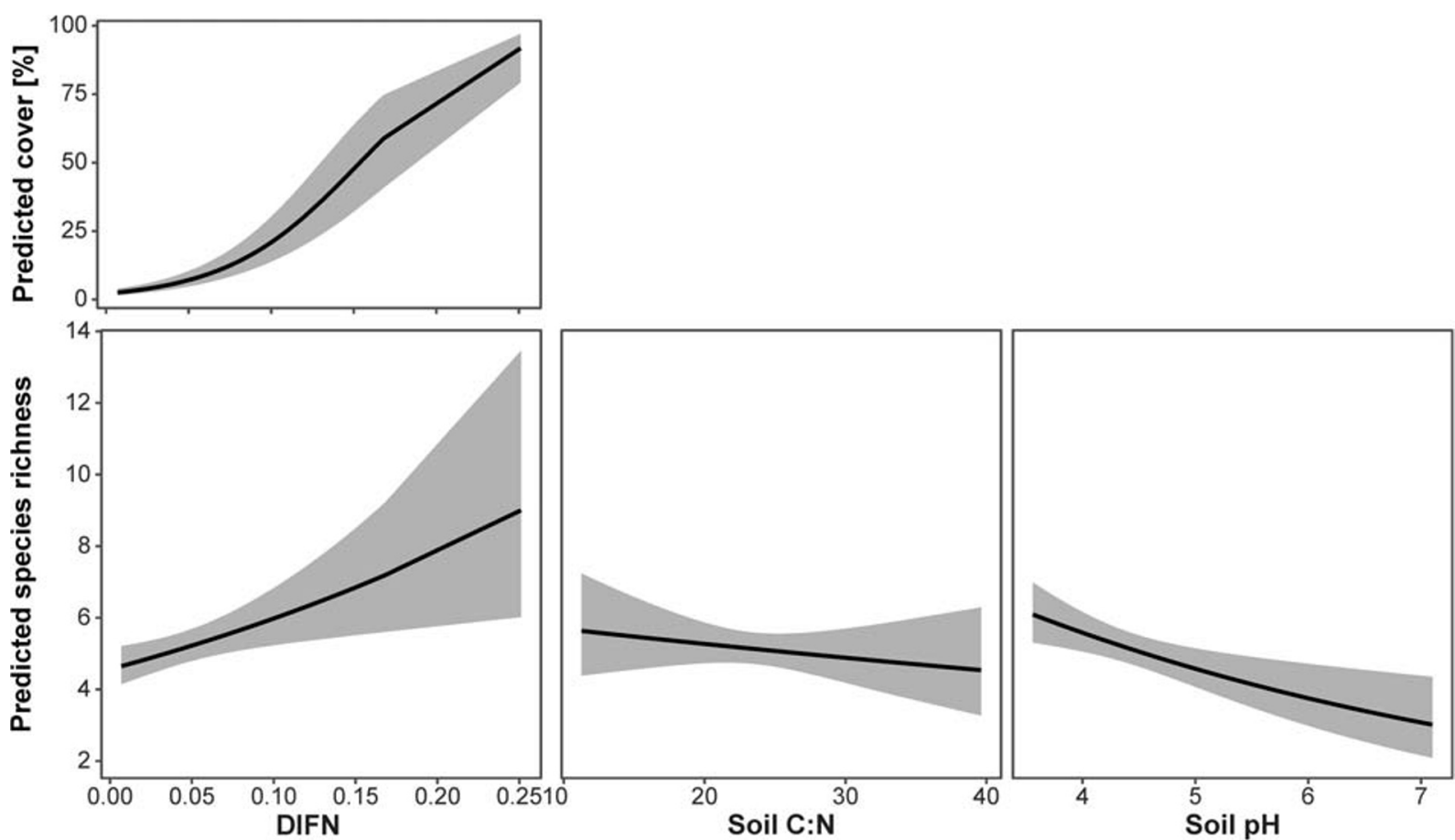

Fig. 5 Marginal responses (+ 95\% CI) of bryophyte species richness per plot and cover for DIFN, soil C:N ratio and soil pH; for model details see Table 4 


\section{Conclusions}

We found that $P$. serotina invaded forests hosted more bryophyte species and had higher species richness than non-invaded in P. sylvestris plantations. Quercus rubra and $R$. pseudoacacia invaded forests hosted fewer bryophyte species but had similar species richness as noninvaded forests. However, these results accounted for adjusted light availability. As most of the previously reported effects of alien tree species on bryophytes did not account for light availability and soil variability, we argue that light limitation by invasive species might be more important than dominant tree species identity in limiting terricolous bryophyte species richness and abundance. This suggestion needs further studies, accounting for varied abundances of invasive species, to assess per capita effects of invaders (Ricciardi et al. 2013; Kumschick et al. 2015). Therefore, conservation of sites with high biodiversity of terricolous bryophytes needs greater insight into modification of canopy cover, as a metric of invasive species impacts.

Supplementary information The online version contains supplementary material available at https://doi.org/10.1007/s12224020-09384-2.

Acknowledgements The study was financed by the National Science Centre, Poland, under the project No. 2015/19/N/NZ8/ 03822 entitled: 'Ecophysiological and ecological determinants of invasiveness of trees and shrubs with the examples of Padus serotina, Quercus rubra and Robinia pseudoacacia'. The study was partially supported by the Institute of Dendrology of the Polish Academy of Sciences.

Authors' contributions Conceptualization: M.K.D and A.M.J.; methodology: M.K.D. and A.M.J.; data collection and formal analysis: M.K.D.; data curation: M.K.D.; writing and original draft preparation: M.K.D.; writing, review and editing: A.M.J.; supervision: A.M.J.; funding acquisition: M.K.D. and A.M.J.Data availabilityThe dataset analysed during the current study is available as electronic supplementary material.

\section{Compliance with ethical standards}

Conflict of interest The authors declare no conflict of interest. The funders had no role in the design of the study; in the collection, analyses, or interpretation of data; in the writing of the manuscript, or in the decision to publish the results.
Ethics approval The study was conducted in Wielkopolski National Park under permissions Nos 25/2014, 7/2105, 7A/2015, 6/2016, 3/2017 and 3/2018

Code availability No custom code was used for analyses; all functions used in data analyses were acknowledged and respective $\mathrm{R}$ packages were cited.

Open Access This article is licensed under a Creative Commons Attribution 4.0 International License, which permits use, sharing, adaptation, distribution and reproduction in any medium or format, as long as you give appropriate credit to the original author(s) and the source, provide a link to the Creative Commons licence, and indicate if changes were made. The images or other third party material in this article are included in the article's Creative Commons licence, unless indicated otherwise in a credit line to the material. If material is not included in the article's Creative Commons licence and your intended use is not permitted by statutory regulation or exceeds the permitted use, you will need to obtain permission directly from the copyright holder. To view a copy of this licence, visit http://creativecommons.org/licenses/by/4.0/.

\section{References}

Barney JN, Tekiela DR, Barrios-Garcia MN, et al (2015) Global Invader Impact Network (GIIN): toward standardized evaluation of the ecological impacts of invasive plants. Ecol \& Evol 5:2878-2889

Brooks M E, Kristensen K, van Benthem KJ, et al (2017) glmmTMB balances speed and flexibility among packages for zero-inflated generalized linear mixed modeling. $R J 9$ : 378

Cáceres MD, Legendre P (2009) Associations between species and groups of sites: indices and statistical inference. Ecology 90:3566-3574

Castro-Díez P, Vaz AS, Silva JS, et al (2019) Global effects of non-native tree species on multiple ecosystem services. Biol Rev 94:1477-1501

Chmura D (2013) Impact of alien tree species Quercus rubra L. on understorey environment and flora: a study of the Silesian Upland (southern Poland). Polish J Ecol 61:431-442

Cierjacks A, Kowarik I, Joshi J, et al (2013) Biological flora of the British Isles: Robinia pseudoacacia. J Ecol 101:1623-1640

Dickie IA, Bennett BM, Burrows LE, et al (2014) Conflicting values: ecosystem services and invasive tree management. Biol Invas 16:705-719

Dickie IA, Bufford JL, Cobb RC, et al (2017) The emerging science of linked plant-fungal invasions. New Phytol 215: 1314-1332

Dyderski MK, Jagodziński AM (2018) Drivers of invasive tree and shrub natural regeneration in temperate forests. Biol Invas 20:2363-2379

Dyderski MK, Jagodziński AM (2019a) Similar impacts of alien and native tree species on understory light availability in a temperate forest. Forests 10:951 
Dyderski MK, Jagodziński AM (2019b) Context-dependence of urban forest vegetation invasion level and alien species' ecological success. Forests 10:26

Dyderski MK, Jagodziński AM (2019c) Seedling survival of Prunus serotina Ehrh., Quercus rubra L. and Robinia pseudoacacia L. in temperate forests of Western Poland. Forest Ecol Managem 450:117498

Dyderski MK, Jagodziński AM (2020) Impact of invasive tree species on natural regeneration species composition, diversity, and density. Forests 11:456

Dyderski MK, Chmura D, Dylewski Ł, et al (2020) Biological flora of the British Isles: Quercus rubra. J Ecol 108:11991225

Engelmann MH, Weaks TE (1985) An analysis of the effects of strip-mining disturbance on bryophyte species diversity. Bryologist 88:344-349

Fritz Ö, Niklasson M, Churski M (2009) Tree age is a key factor for the conservation of epiphytic lichens and bryophytes in beech forests. Appl Veg Sci 12:93-106

Fudali E, Szymanowski M (2019) Epiphytic bryophytes on alien host-tree species in Wrocław (SW Poland). Cryptog Bryol 40:117

Gentili R, Ferrè C, Cardarelli E, et al (2019) Comparing negative impacts of Prunus serotina, Quercus rubra and Robinia pseudoacacia on native forest ecosystems. Forests 10:842

González-Moreno P, Diez JM, Ibáñez I, et al (2014) Plant invasions are context-dependent: multiscale effects of climate, human activity and habitat. Diversity \& Distrib 20:720-731

Gustafsson L, Hallingbäck T (1988) Bryophyte flora and vegetation of managed and virgin coniferous forests in South-West Sweden. Biol Conservation 44:283-300

Halarewicz A, Pruchniewicz D (2015) Vegetation and environmental changes in a Scots pine forest invaded by Prunus serotina: What is the threat to terricolous bryophytes? Eur $J$ For Res 134:793-801

Hartig F (2020) DHARMa: Residual diagnostics for hierarchical (multi-level / mixed) regression models. $R$ package version 0.2.7. Available at https://cran.r-project.org/package $=$ DHARMa (Accessed 14 Oct 2020)

Hodgetts NG, Söderström L, Blockeel TL, et al (2020) An annotated checklist of bryophytes of Europe, Macaronesia and Cyprus. J Bryol 42:1-116

Jagodziński AM, Dyderski MK, Rawlik M, Banaszczak P (2015) Plantation of coniferous trees modifies risk and size of Padus serotina (Ehrh.) Borkh. invasion - evidence from a Rogów arboretum case study. Forest Ecol Managem 357:84-94

Jagodziński AM, Wierzcholska S, Dyderski MK, et al (2018) Tree species effects on bryophyte guilds on a reclaimed postmining site. Ecol Engin 110:117-127

Jagodziński AM, Dyderski MK, Horodecki P, et al (2019) Light and propagule pressure affect invasion intensity of Prunus serotina in a 14-tree species forest common garden experiment. NeoBiota 46:1-21

Karolewski P, Łukowski A, Adamczyk D, et al (2020) Species composition of arthropods on six understory plant species growing in high and low light conditions. Dendrobiology 84 : $58-80$

Király I, Ódor P (2010) The effect of stand structure and tree species composition on epiphytic bryophytes in mixed deciduous-coniferous forests of Western Hungary. Biol Conservation 143:2063-2069
Király I, Nascimbene J, Tinya F, Ódor P (2013) Factors influencing epiphytic bryophyte and lichen species richness at different spatial scales in managed temperate forests. Biodivers \& Conservation 22:209-223

Kriebitzsch W-U, Bültmann H, von Oheimb G, et al (2013) Forest-specific diversity of vascular plants, bryophytes, and lichens. In Kraus D, Krumm F (eds) Integrative approaches as an opportunity for the conservation of forest biodiversity. European Forest Institute. Joensuu, pp. 158-169

Kumschick S, Gaertner M, Vilà M, et al (2015) Ecological impacts of alien species: quantification, scope, caveats, and recommendations. BioScience 65:55-63

Lenth R (2019) emmeans: Estimated Marginal Means, aka LeastSquares Means. Version 1.3.5.1. Available at https://CRAN. R-project.org/package=emmeans (Accessed 14 Oct 2020)

Lövei GL (1997) Global change through invasion. Nature 388: $627-628$

Lüdecke D (2018) ggeffects: didy data frames of marginal effects from regression models. J Statist Softw 3:772

Mack RN, Simberloff D, Mark Lonsdale W, et al (2000) Biotic invasions: causes, epidemiology, global consequences, and control. Ecol Applic 10:689-710

Magni Diaz CR (2004) Reconstitution de l'introduction de Quercus rubra L. en Europe et conséquences génétiques dans les populations allochtones. l'Ecole Nationale du Génie Rural, des Eaux et des Forêts, Paris

Major KC, Nosko P, Kuehne C, et al (2013) Regeneration dynamics of non-native northern red oak (Quercus rubra L.) populations as influenced by environmental factors: a case study in managed hardwood forests of southwestern Germany. Forest Ecol Managem 291:144-153

Mežaka A, Brūmelis G, Piterāns A (2012) Tree and stand-scale factors affecting richness and composition of epiphytic bryophytes and lichens in deciduous woodland key habitats. Biodivers \& Conservation 21:3221-3241

Mueller KE, Eissenstat DM, Hobbie SE, et al (2012) Tree species effects on coupled cycles of carbon, nitrogen, and acidity in mineral soils at a common garden experiment. Biogeochemistry 111:601-614

Mueller KE, Eisenhauer N, Reich PB, et al (2016) Light, earthworms, and soil resources as predictors of diversity of 10 soil invertebrate groups across monocultures of 14 tree species. Soil Biol Biochem 92:184-198

Muukkonen P, Makipaa R, Laiho R, et al (2006) Relationship between biomass and percentage cover in understorey vegetation of boreal coniferous forests. Silva Fenn 40:231-245

Niinemets Ü (2010) A review of light interception in plant stands from leaf to canopy in different plant functional types and in species with varying shade tolerance. Ecol Res 25:693-714

Novoa A, Richardson DM, Pyšek P, et al (2020) Invasion syndromes: a systematic approach for predicting biological invasions and facilitating effective management. Biol Invas 22: $1801-1820$

Oksanen J, Blanchet FG, Kindt R, et al (2018) 'vegan' - community ecology package. Version 2.3.3. Available at http://CRAN.R-project.org/package=vegan $($ Accessed 14 Oct 2020)

Peterken GF (2001) Ecological effects of introduced tree species in Britain. Forest Ecol Managem 1 41:31-42 
Pharo EJ, Lindenmayer DB (2009) Biological legacies soften pine plantation effects for bryophytes. Biodivers \& Conservation 18:1751-1764

Potgieter LJ, Gaertner M, Kueffer C, et al (2017) Alien plants as mediators of ecosystem services and disservices in urban systems: a global review. Biol Invas 19:3571-3588

Purcel A (2009) Obce gatunki drzew i krzewów w Wielkopolskim Parku Narodowym - ich występowanie i rola w biocenozach Parku. Morena 14:35-191

Quine CP, Humphrey JW (2010) Plantations of exotic tree species in Britain: irrelevant for biodiversity or novel habitat for native species? Biodivers \& Conservation 19:1503-1512

$\mathrm{R}$ Core Team (2019) $R$ : A language and environment for statistical computing. R Foundation for Statistical Computing, Vienna, Austria

Rejmánek M, Richardson DM (2013) Trees and shrubs as invasive alien species - 2013 update of the global database. Diversity \& Distrib 19:1093-1094

Ricciardi A, Hoopes MF, Marchetti MP, Lockwood JL (2013) Progress toward understanding the ecological impacts of nonnative species. Ecol Monogr 83:263-282

Richardson DM, Rejmánek M (2011) Trees and shrubs as invasive alien species - a global review. Divers \& Distrib 17:788-809

Riepšas E, Straigyté L (2008) Invasiveness and Ecological Effects of Red Oak (Quercus rubra L.) in Lithuanian Forests. Baltic Forest 14:122-130

Rożek K, Rola K, Błaszkowski J, et al (2020) How do monocultures of fourteen forest tree species affect arbuscular mycorrhizal fungi abundance and species richness and composition in soil? Forest Ecol Managem 465:118091

Rydin H (2008) Population and community ecology of bryophytes. In Goffinet B, Shaw AJ (eds) Bryophyte biology. Second Edition. Cambridge University Press, Cambridge, pp. 393-444

Sapsford SJ, Brandt AJ, Davis KT, et al (2020) Towards a framework for understanding the context-dependence of impacts of non-native tree species. Funct Ecol 34:944-955

Säumel I, Kowarik I (2013) Propagule morphology and river characteristics shape secondary water dispersal in tree species. Pl Ecol 214:1257-1272

Sitzia T, Campagnaro T, Kotze DJ, et al (2018) The invasion of abandoned fields by a major alien tree filters understory plant traits in novel forest ecosystems. Sci Rep 8:8410

Slabejová D, Bacigál T, Hegedüšová K, et al (2019) Comparison of the understory vegetation of native forests and adjacent Robinia pseudoacacia plantations in the CarpathianPannonian region. Forest Ecol Managem 439:28-40

Snäll T, Hagström A, Rudolphi J, Rydin H (2004) Distribution pattern of the epiphyte Neckera pennata on three spatial scales - importance of past landscape structure, connectivity and local conditions. Ecography 27:757-766

Stanek M, Stefanowicz AM (2019) Invasive Quercus rubra negatively affected soil microbial communities relative to native Quercus robur in a semi-natural forest. Sci Total Environm 696:133977

Starfinger U, Kowarik I, Rode M, Schepker H (2003) From desirable ornamental plant to pest to accepted addition to the flora? - the perception of an alien tree species through the centuries. Biol Invas 5:323-335

Taylor KT, Maxwell BD, Pauchard A, et al (2016) Native versus non-native invasions: similarities and differences in the biodiversity impacts of Pinus contorta in introduced and native ranges. Diversity \& Distrib 22:578-588

Urban J, Tatarinov F, Nadezhdina N, et al (2009) Crown structure and leaf area of the understorey species Prunus serotina. Trees 23:391-399

Vanderpoorten A, Engels P, Sotiaux A (2004) Trends in diversity and abundance of obligate epiphytic bryophytes in a highly managed landscape. Ecography 27:567-576

Vegini E, Lastrucci L, Lazzaro L, et al (2020) Impact of Prunus serotina Ehrh. invasion on heathland vegetation: a case of study in North-Western Italy. Biologia 75:327-336

Verheyen K, Vanhellemont M, Stock T, Hermy M (2007) Predicting patterns of invasion by black cherry (Prunus serotina Ehrh.) in Flanders (Belgium) and its impact on the forest understorey community. Diversity \& Distrib 13:487497

Vilà M, Espinar JL, Hejda M, et al (2011) Ecological impacts of invasive alien plants: a meta-analysis of their effects on species, communities and ecosystems. Ecol Letters 14:702708

Vítková M, Müllerová J, Sádlo J, et al (2017) Black locust (Robinia pseudoacacia) beloved and despised: A story of an invasive tree in Central Europe. Forest Ecol Managem 384:287-302

Vitousek PM, Mooney HA, Lubchenco J, Melillo JM (1997) Human domination of Earth's ecosystems. Science 277: 494-499

Wagner V, Chytrý M, Jiménez-Alfaro B, et al (2017) Alien plant invasions in European woodlands. Diversity \& Distrib 23: 969-981

Wierzcholska S, Dyderski MK, Pielech R, et al (2018) Natural forest remnants as refugia for bryophyte diversity in a transformed mountain river valley landscape. Sci Total Environm 640-641:954-964

Wirth C, Schulze E-D, Schulze W, et al (1999) Above-ground biomass and structure of pristine Siberian Scots pine forests as controlled by competition and fire. Oecologia 121:66-80

Woziwoda B, Parzych A, Kopeć D (2014) Species diversity, biomass accumulation and carbon sequestration in the understorey of post-agricultural Scots pine forests. Silva Fenn 48:1119

Woziwoda B, Staniaszek-Kik M, Stefańska-Krzaczek E (2017) Assemblages of native bryophytes in secondary forests with introduced Quercus rubra. Nordic J Bot 35:111-120

Zerbe S, Wirth P (2006) Non-indigenous plant species and their ecological range in Central European pine (Pinus sylvestris L.) forests. Ann Forest Sci 63:189-203

Publisher's note Springer Nature remains neutral with regard to jurisdictional claims in published maps and institutional affiliations. 